\title{
THE ATTEMPT TO ASSESS THE TECHNICAL CONDITION OF A GAS TURBINE BLADE WHEN INFORMATION ON ITS OPERATING CONDITION IS LIMITED
}

\section{PRÓBA OCENY STANU LOPATKI TURBINY GAZOWEJ W PRZYPADKU OGRANICZONEJ INFORMACJI O WARUNKACH JEJ EKSPLOATACJI}

\author{
Józef Błachnio $^{1}$, Jarosław Spychała ${ }^{1}$, Wojciech Pawlak ${ }^{1}$, Dariusz Zasada ${ }^{2}$ \\ ${ }^{1}$ Air Force Institute of Technology, Warsaw, \\ ${ }^{2}$ Military University of Technology, Warsaw, \\ e-mail: jozef.blachnio@itwl.pl, jaroslaw.spychala@itwl.pl, \\ wojciech.pawlak@itwl.pldzasada@wat.edu.pl
}

\begin{abstract}
The paper discloses a non-invasive method of visual inspection based on processing of images taken for blade surfaces in the spectrum of visible light and then analyzed with the use of a computer-aided technology. The method of computeraided analysis of images for blade surfaces is presented in details along with the obtained outcome, whilst the results from metallographic investigation of the blade superalloy are disclosed as well. The comparison is made between the results obtained from the analysis of images for blade surface and the results from the metallographic investigation of their structures. Finally, the relationship is established between parameters of digital images taken for surfaces of gas turbine blades in the visible spectrum of electromagnetic waves and microstructural parameters of the turbine blade metal. The completed investigations and analyses reveal that troubleshooting of gas turbine blades, which employs digital processing of images taken for its surface, offers new opportunities to determine the condition of blades after a long-term impact of a working agent at high temperature.
\end{abstract}

Keywords: gas turbine, blade, diagnosis blades

Streszczenie: $W$ artykule omówiono nieinwazyjna metode wizualna oparta na przetwarzaniu obrazów powierzchni $w$ świetle widzialnym $z$ wykorzystaniem wspomagania komputerowego. Przedstawiono sposób komputerowej analizy obrazów powierzchni topatek oraz jej wyniki. Zaprezentowano wyniki badań metalograficznych nadstopu topatek. Porównano uzyskane wyniki analizy obrazów powierzchni topatek $z$ wynikami badań metalograficznych ich struktury. W rezultacie ustalono zwiazek pomiędzy parametrem cyfrowych obrazów powierzchni topatek turbiny gazowej, w paśmie widzialnym fali elektromagnetycznej, a parametrami ich mikrostruktury. $Z$ zaprezentowanych badań $i$ analiz wynika, że diagnozowanie topatek turbiny gazowej metoda cyfrowego przetwarzania obrazów ich powierzchni, daje nowe możliwości określenia stanu topatek po oddziatywaniu czynnika roboczego o wysokiej temperaturze.

Stowa kluczowe: turbina gazowa, topatka turbiny, diagnozowanie topatek 
Condition of a gas turbine blade when information on its operating condition... Próba oceny stanu topatki turbiny gazowej w przypadku ograniczonej informacji...

\section{Introduction}

Each turbine is a rotary fluid-flow machine that converts enthalpy of a working agent, also referred to as the thermodynamic agent (stream of exhaust gas, gas products of fuel decomposition or compressed gas), into usable work that entails revolutions of the turbine rotor. For avionic applications, gas turbines are structural components of turbojet, turboprop or helicopter engines. Power of the turbine is crucial for the engine performance and each improvement of its efficiency leads to increase of the engine thrust (power) and reduction of fuel consumption per power unit. Operation of turbines entails wear and tear processes, where turbine blades are the components most exposed to damage and their technical condition is crucial for reliability and operation lifetime of both the entire turbine and the unit where the turbine is installed [9]. Durability of turbine blades is a superposition of many factors, where the turbine material is the most important one. In terms of the material durability, the lifetime can be defined as the time of the turbine operation when properties of the alloy remain intact, just the same as after the manufacturing process. Invariability of the alloy properties (assumed lifetime resource) can be achieved as early as in the engineering phase by selection of sufficiently reliable characteristics of the material (as compared to expected loads and with consideration to variations of these characteristics in pace with the turbine operation). In terms of the material structure, the perfect and steady characteristics of the material are achieved by its appropriate microstructure that is immune to weakening during the turbine operation. These are the structural criteria that are adopted as the criterion of durability $[4,6,10]$.

The components of a gas turbine are subject to deterioration during its operation as a result of the following processes $[1,2,4,8,11]$ :

- Overheating and melting.

- Material creeping.

- Thermal and thermomechanical fatigue associated with high frequency and low frequency thermal cycles.

- Cracking due to corrosion and fatigue of materials.

- Chemical and intercrystalline corrosion.

- Erosion.

- Plastic (irreversible) deformations.

- Others.

A predominant majority of defects affecting gas turbine blades is caused by improper operation (adjustment) of subassemblies collaborating with the turbine, chiefly the combustion chamber and, in case of turbines in avionic turbojet engines, also the exhaust nozzle (in particular the mechanism for adjustment of its discharge cross-section).

Other reasons for overheating of blades include exceeding of the maximum permissible temperature of the exhaust gas upstream the turbine and non-uniform distribution of the exhaust gas temperature down the perimeter of the combustion 
chamber [8]. Important reasons for a non-uniform distribution of temperature comprise disturbed spraying of fuel due to deposition of carbon black on injectors and incomplete combustion of fuel inside the combustion chamber [3].

a)

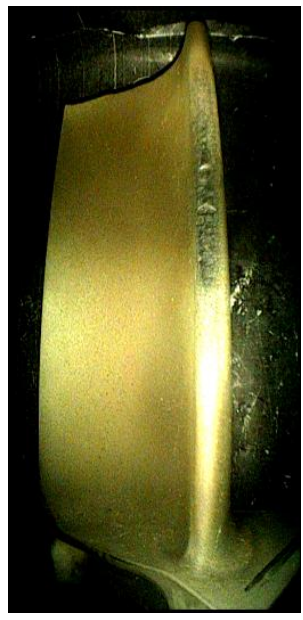

b)

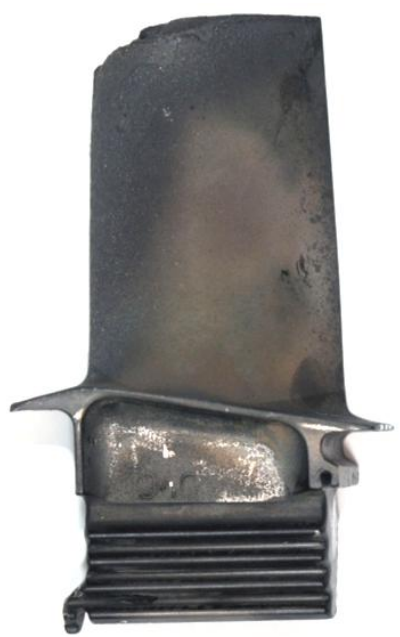

c)

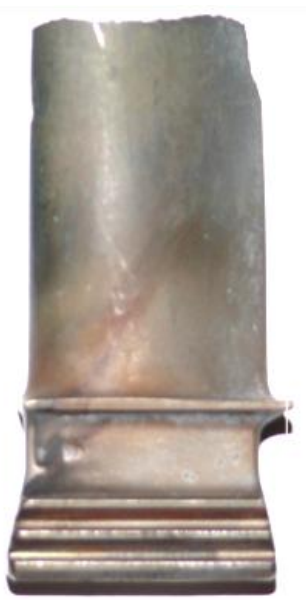

Fig. 1 Examples for deterioration of turbine blades caused by excessive temperature of the exhaust gas: a) overheating and cracks on the leading edge; b) burn-out of the tip end; c) tip end tear off [9]

The objective of troubleshooting procedures is to assess the technical condition of machinery components and to decide whether or not they are still suitable for further operation. Troubleshooting engineers should also make predictions about the component condition during both the upcoming and long-lasting time periods. In case of non-destructive tests (NDT), the assessment is sometimes based on subjective impressions of the test engineer. It is why jobs performed by them are extremely responsible due to the need to make a decision whether or not the component is still good enough for further use. On one hand, there is a risk of replacing and discarding a part which could possibly be in service for a long time, but on the other hand, leaving a suspicious part in service may lead to a fatal accident caused by its excessive wear and tear. The ability of a human to correctly assess the technical condition of a machine depends on a series of external factors; therefore, efforts have been commenced to develop objective tools for assessment of the technical condition demonstrated by machinery parts. Continuous progress in digital technologies is conducive to computerization of all maintenance processes, including troubleshooting procedures. Development of a relevant algorithm for computer-aided judging whether or not a specific part is still in 
Condition of a gas turbine blade when information on its operating condition... Próba oceny stanu topatki turbiny gazowej w przypadku ograniczonej informacji...

service condition requires a selection of a set and form of input signals and parameters that shall be subjected to the analysis [4].

Reliability of the technical condition assessment stems from a series of factors, e.g. skills and experience of test engineers, troubleshooting methods, reliability of troubleshooting instruments, external conditions of the experiment, etc. Errors in subjective assessment of a test engineer may lead to aliasing of faults when an overheated blade can be considered as a good one or vice versa [2]. In the first case, an avionic fatal incident may happen in a short time, whilst the latter one entails a very expensive and time consuming major overhaul of the engine. In some cases, troubleshooting of the turbine blade condition may employ not only the sharp classification "good - not good" but also a third result of the assessment "the part is provisionally suitable for operation". It also refers to gas turbines which are incorporated into structures of avionic turbojet engines, i.e. the expensive machinery where the relationship between lifetime of components and operational expenses should be kept at the maximum possible reasonable level. It is why the three-step scale is used in cases when the overheating degree manifested by intensity of blade discoloration and the size and location of the discoloured area on the blade surface subjects to discrete assessment by the test engineer. Should the overheating degree of the blade be considered as "provisionally suitable", further inspections of the blade condition are carried out on regular basis until the blade reaches the "not good" status. It enables extension of the service life (MTTF) of the turbine (alike the expensive avionic engine) and makes it possible to operate the engine even if the blades are insignificantly damaged with reduction of the entire operation expenses of the turbine. Obviously, in no way may it compromise flight safety of the aircraft where the engine with the continuously monitored turbine is installed.

\section{Methods for assessment of the technical condition demonstrated by blades of gas turbines}

Despite the fact that destructive investigations, i.e. metallographic tests, provide much more information about the material structure of the object under test, such investigations eventually disable further operation of the object. It is why the most widespread method of investigation of the blade condition is visual inspection. The method assumes the use of various optoelectronic equipment, like videoscopes or analyzer of video images. Such appliances enable acquisition of photographs from poorly accessible machinery components and confined areas. The device consists of a central control unit used as a portable computer workstation which enables management of acquired information and an inspection camera provided with a powerful source of light.

Images acquired for surfaces of gas turbine blades are stored in the form of digitalized images with the 24-bit data length and the RGB imaging system [2]. It is the basic format for colour images which makes it possible to use as much as 16777216 colours, since each basic colour (red, green and blue) may adopt 256 different shades. 
Any colour can be expressed by three numbers ranging from 0 to 255 . White colour is encoded by three numbers [255, 255, 255] whilst black colour corresponds to the Cartesian product of $[0,0,0]$.

The RGB model substantially differs from the manner in which colours are identified by human eye, where the process of colour recognition is based on evaluation of its attributes [2]. The colour attribute is understood as a characteristic and inseparable feature used to define one of the three following properties: (i) colour shade (colour, hue) - quality difference of colours, (ii) saturation deviation of the specific colour from whiteness, (iii) brightness - indicates whether the specific colour is closer to whiteness or darkness.

Processing and analysis of acquired images were carried out with dedicated software routines developed in the Matlab environment. The use of these routines made it possible to obtain parameters which serve to assess whether and how much the blade feather is damaged due to overheating of its material. These parameters are determined from a histogram for brightness distribution . For digital images, the histogram represents how often specific values of pixels occur in the image. The $\mathrm{X}$ axis counts subsequent values of brightness level from 0 , which stands for blackness, up to 255 which corresponds to whiteness. On the other hand, the Y-axis indicates the number of image pixels with various levels of brightness. Histograms can be plotted not only for black and white images but also for each basic colour, where zero stands for the darkest shade of the colour and 255 corresponds to the brightest one.

Histograms are represented by a vector, where its length is equal to the number of brightness levels for the specific image, thus it can be expressed in the following way [2]:

$$
H\left(l_{k}\right)=\sum_{m=1}^{M} \sum_{n=1}^{N} p\left(l_{k},(m, n)\right)
$$

where: $H\left(l_{k}\right)$-totalized number of points with the $l_{k}$ level of brightness, and

$$
p\left(l_{k},(m, n)\right)=\left\{\begin{array}{l}
1 ; \text { for } L(m, n)=l_{k} \\
0 ; \text { for } L(m, n) \neq l_{k}
\end{array}\right.
$$

Moreover, the histogram can be expressed in the normalized form, where each value of the histogram is divided by the total number of image pixels $(M \cdot N)$.

$$
H_{z n}\left(l_{k}\right)=\frac{\sum_{m=1}^{M} \sum_{n=1}^{N} p\left(l_{k},(m, n)\right)}{M \cdot N}
$$


Condition of a gas turbine blade when information on its operating condition... Próba oceny stanu topatki turbiny gazowej w przypadku ograniczonej informacji...

\section{Investigation results}

Investigations were carried out for blades of the first stage (circle) of the avionic turbine rotor. Blades were manufactured by casting of nickel and cobalt alloy. The blades are cooled from the inside by an air stream bled from a location downstream the turbine compressor.

The examinations were carried out for a new blade and blades that have already been in use. Initially, the used blades were visually classified by the colour of the leading edge and sorted by the increasing area of the blade discolouration. Blade discolouration and the area of discoloured surface serve as the symptom for blade deterioration due to the effect of combustion gas (thermal and mechanical impact). Images for leading edges were acquired for individual blades by means of a videoscope. To obtains images without interferences (reflections of light), the blades were placed in a dedicated chamber capable of light absorbing (with black walls) (Fig. 2).
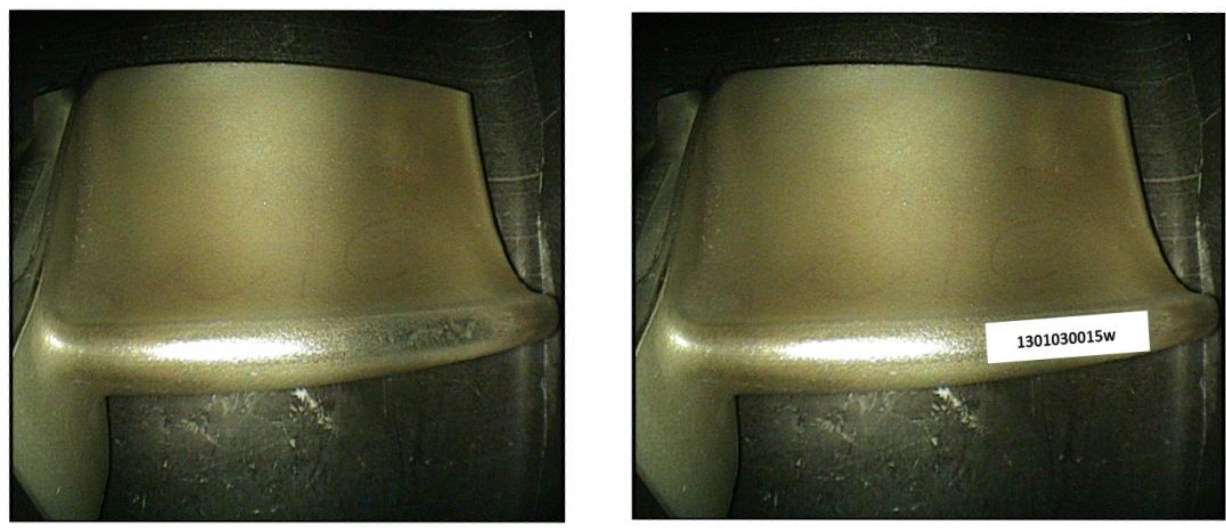

Fig. 2 Examples of images for leading edges acquired for used blades and damaged fragment of that edge adopted for statistical analysis.

The acquired images were then processed by means of bespoken software to achieve plots for histogram envelopes and to determine the maximum brightness which corresponds to the maximum saturation. Due to the irregular shape of the plotted histograms, it proved difficult to find the level of brightness adopted by the largest number of pixels. For that reason, a low-pass Butterworth filter of 4th rank was adopted [8], which allowed smoothing of the histogram plot and determination of the brightness level associated with the maximum saturation (Fig. 3).

The histograms of brightness distribution for images of leading edges were then used to establish statistical parameters for each blade. The most important parameter is the saturation level for grey shades referred to as "RO saturation", since it reflects the average level of grey shade for the blade surface under investigation. It was demonstrated that the area of a damaged leading edge increases in pace with deterioration of the technical condition demonstrated by blades. In addition, the colour of that surface subjects to variations as well, from light brown through grey to dark grey. It entails decreasing of the brightness level - RO saturation - towards the dark shade of grey (Fig. 4). 
Initial assessment provided by the test engineer is then verified by the destructive method. The blade under test undergoes analysis of its microstructure on a metallographic polished section. The assessment consists of examination of microstructure demonstrated by blades which have already been in use, comparison of the outcome against the microstructure of a brand new (reference) blade and execution of the diagnostic inferring process to make the final decision with regard to the blade condition.
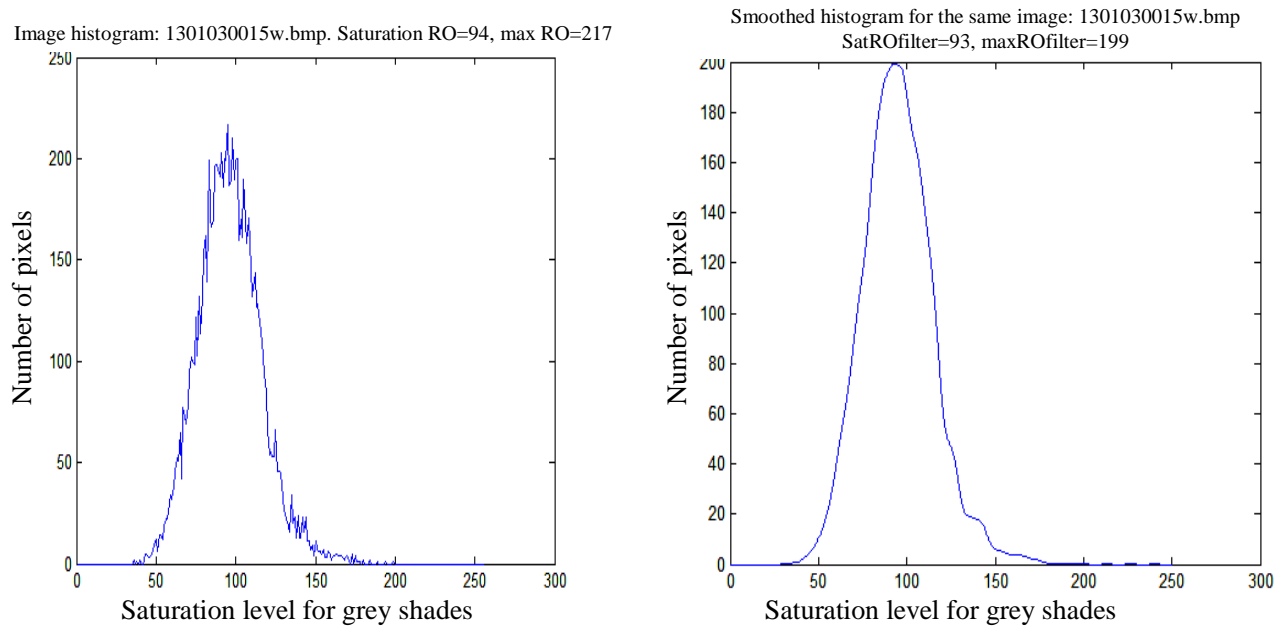

Fig. 3 Graphs for statistic parameters of the $1^{\text {st }}$ range for images of leading edges from Fig. 2, before and after application of the Butterworth filter of $4^{\text {th }}$ rank.

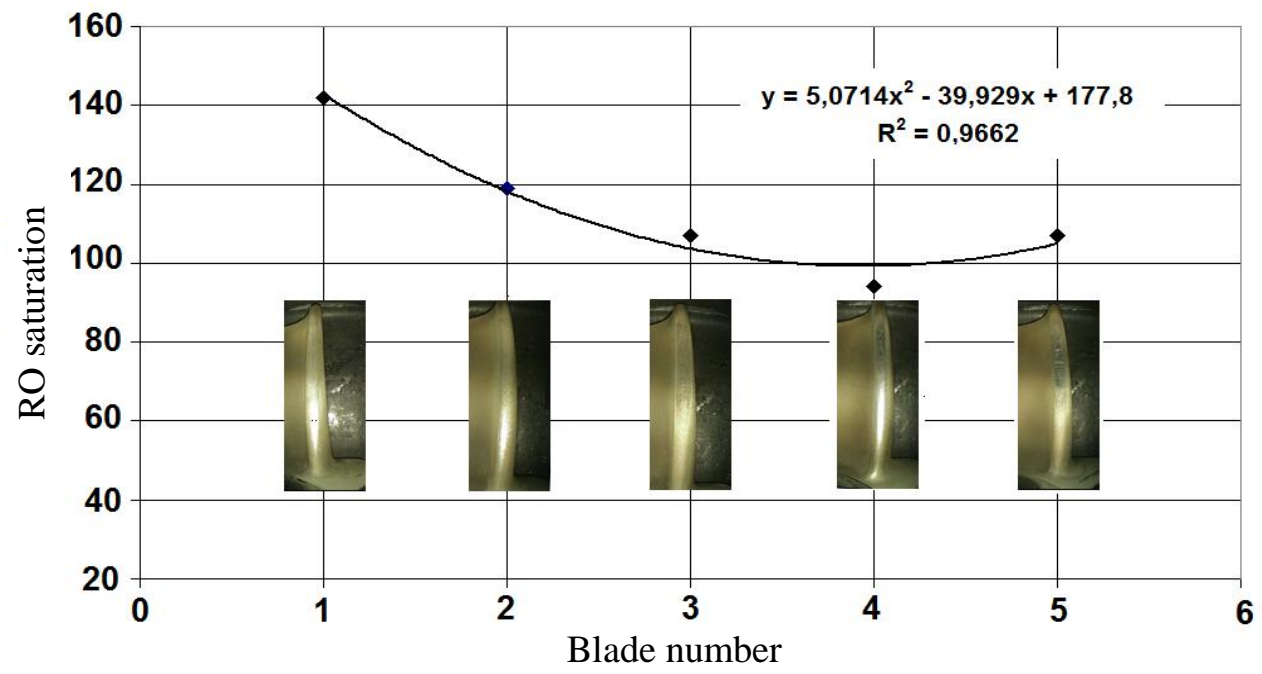

Fig. 4 Graph for statistic parameters of the $1^{\text {st }}$ range in the form of the relationship between " $R O$ saturation" and the colours expressed by grey shades on the leading edge of individual blades. 
Condition of a gas turbine blade when information on its operating condition...

Próba oceny stanu topatki turbiny gazowej w przypadku ograniczonej informacji...

Investigations of the blade microstructures were carried out for samples already cut out from blades. After grinding and mechanical polishing, the samples were etched with the use of the Kallings reagent. Observations and recording of images were carried out with the use of both an optical and a scanning microscope. The typical structure of a blade superalloy was determined on crosswise metallographic polished microsections completed for the leading edges of individual blades (Fig. 5).

a)

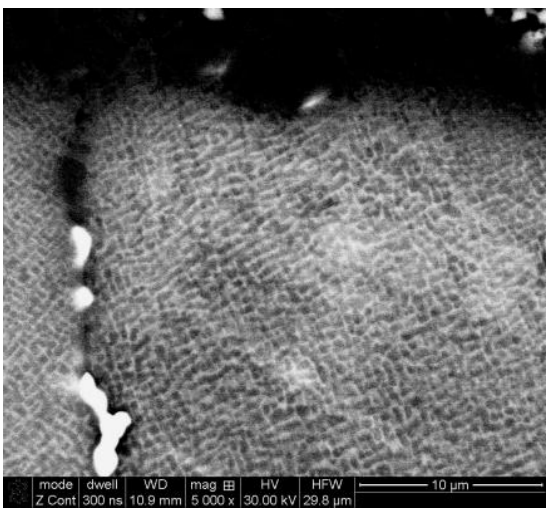

c)

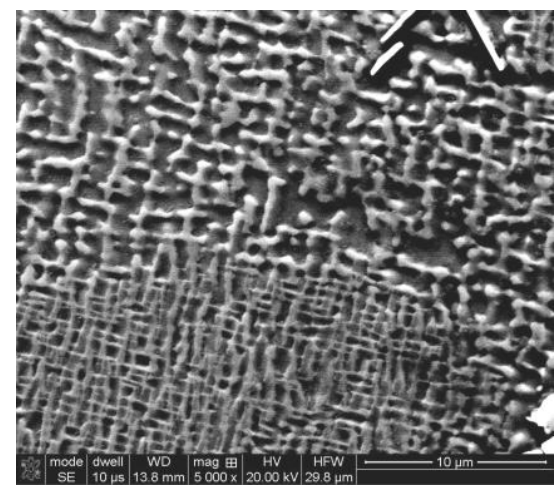

b)

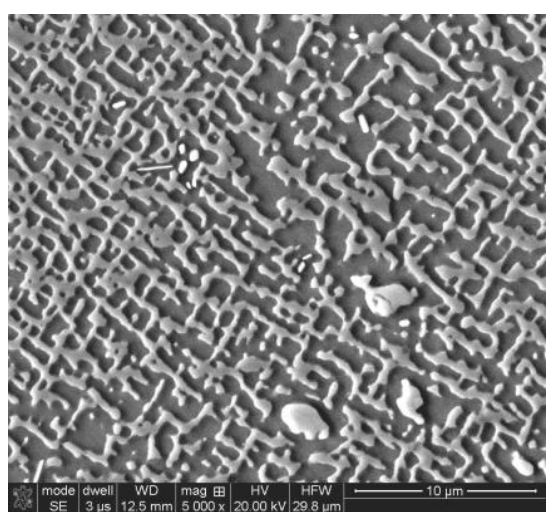

d)

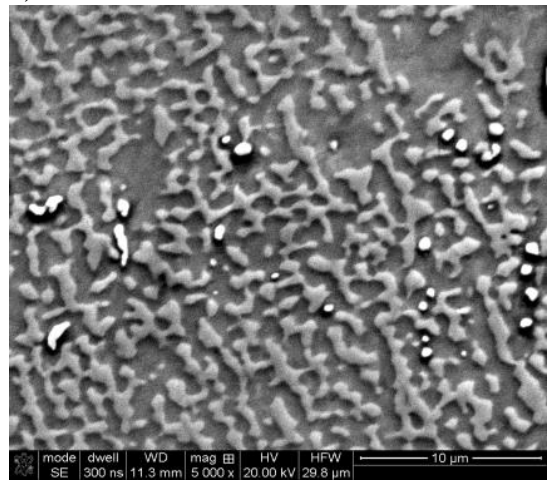

e)

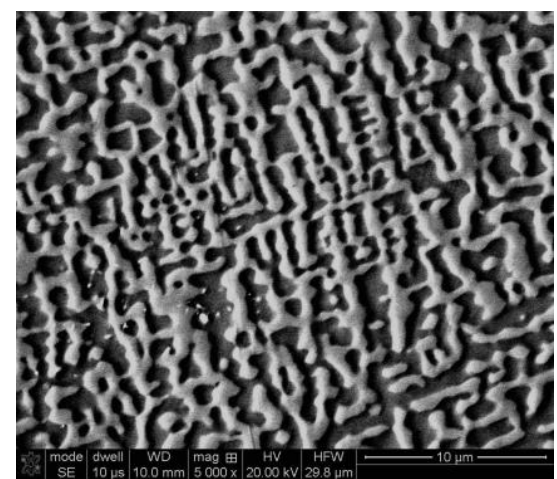

Fig. 5 Microstructures for the superalloy samples from the leading edges of blades: a) brand new blade No. 1; used blades: b) -No. 2; c) -No. 3; d)-No. 4; e) -No. 5 . 
Metallographic investigations of blades that have already been in use made it possible to detect alterations of their microstructure as compared to a brand new blade. First and foremost, changes took place in the morphology of intermetallic (reinforcing) particles of the $\gamma^{\prime}$ phase (Fig. 5).

It was established that microstructures of both heat resistant coating and the parent metal have altered in pace with deterioration of the technical condition demonstrated by the blades and manifested by discolouration of the leading edge. Comparison of results from the statistical analysis (Fig. 4) against the outcome from investigation of microstructure alterations makes it possible to establish that decrease of "RO saturation" is associated with coagulation of particles within the intermetallic $\gamma$ ' phase (Fig. 5). The minimum level of "RO saturation" occurs between the blades No. 4 (considered as overheated and unsuitable for use) and No. 5 (also considered as overheated, cracked and unsuitable for further use). Shades of cracks on the leading edge are brighter than the overheated surface; therefore, the "RO saturation" parameter is slightly higher for the blade No. 5 than the one for blade No. 4.

Morphology of the $\gamma^{\prime}$ phase depends on the sign of mechanical relaxation. Axial tensile force whichaffects the blade when the turbine rotor revolves is conducive to expansion of the $\gamma^{\prime}$ phase down the plane perpendicular to the tensile force vector [5]. It leads to formation of plates (Fig. 5e) from the primary cubical shapes of particles (Fig. 5a), where the wider planes of the plates extend perpendicularly to the tensile force vector whilst the narrow sides are perpendicular to other edges of the cube [6].

Expansion of the $\gamma^{\prime}$ phase particles leads to deterioration of their stability, which results in coagulation of some particles and dissolving of other ones. That process takes place at a specific temperature and duration of exhaust gas impact characteristic for each phase. According to the authors of the study [5], exceeding of the temperature of $1223 \mathrm{~K}$ triggers intense volumetric expansions of the $\gamma^{\prime}$ formation phase even if the duration of the temperature impact is pretty short, which leads to loss of the shape stability and formation of the intermetallic plates. Similar results were achieved in the study [7] where the Udimet 700 alloy was investigated. Structures in the form of intermetallic plates presented less impact onto the offset yield stress than in the case of cubical formations when the temperature exceeds $1093 \mathrm{~K}$.

Kinetic features of phase $\gamma^{\prime}$ formations depends on the saturation degree with alloy elements of the $\gamma$ phase, whilst shapes of intermetallic formation depend on the degree of incompatibility between their lattice and the lattice of the alloy matrix. When the incompatibility degree is $\Delta a=0.2 \%$, the intermetallic phase $\gamma^{\prime}$ is formed as spherical structures; at $\Delta a=0.5-1 \%$, it adopts the cubical shape, whilst at $\Delta a=1.2 \%$, it forms shapes of plates [7]. The theory of formation reinforcements by intermetallic phases says that the crucial factors deciding about the reinforcement degree are the diameter of $\gamma^{\prime}$ particles and the space between them. 
Condition of a gas turbine blade when information on its operating condition...

Próba oceny stanu topatki turbiny gazowej w przypadku ograniczonej informacji...

These parameters depend on the rates of the $\gamma^{\prime}$ phase particles extension and of their coagulation $[7,10]$.

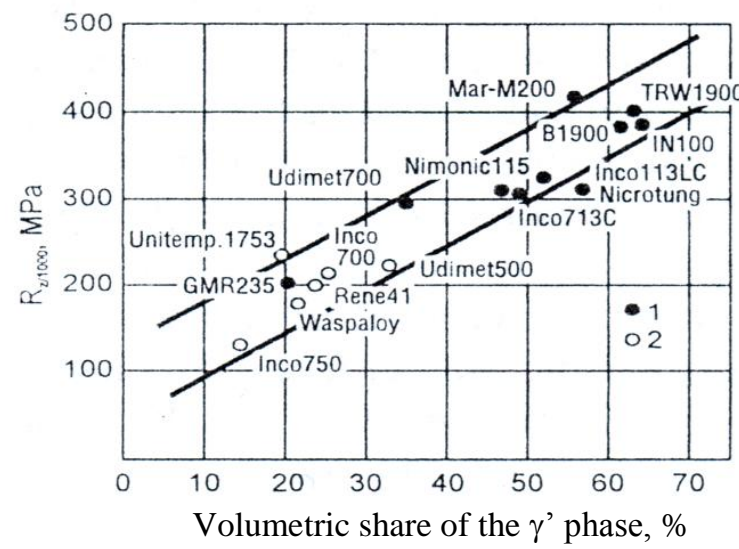

Fig.6 Interrelationship between shares of the $\gamma^{\prime}$ phase particles and creeping resistance $R_{z} / 1000$ at the temperature $1090 \mathrm{~K}$ plotted for nickel alloys [7]:

$$
1 \text { - cast alloys; } 2 \text { - cold formed alloys. }
$$

The chemical composition of the $\gamma^{\prime}$ phase substantially affects the value $a \gamma^{\prime}$ of its lattice parameter and associated degree $\Delta a$ of incompatibility with the matrix lattice $a \gamma$, where $\Delta a=\left(a \gamma-a \gamma^{\prime}\right) / a \gamma$. It affects the morphology of phase $\gamma^{\prime}$ formations and ranges of its durability. It turns out that the incompatibility degree is a function of temperature. According to the author of the study [7], the highest degree of heat resistance is found in the alloys with a positive value of the incompatibility factor for lattices of these two phases. When the degree of incompatibility between lattices grows from 0.16 to 0.80 , the tensile strength of alloys containing $\mathrm{Nb}$ and $\mathrm{Ta}$ elements grows by more than $200 \mathrm{MPa}$ at the temperature of $1130 \mathrm{~K}[7,10]$.

Chemical composition, morphology and deployment of the $\gamma^{\prime}$ phase within the structure of formations have crucial impact on the strength properties of superalloys (Fig. 6). Extension of that phase leads to coagulation of formations and alteration of their shapes from cubical into plate structures. In addition, its percentage share within the alloy structure is diminished, which leads to decay of such alloy parameters as heat resistance and high temperature creep resistance.

\section{Recapitulation and conclusions}

The deterioration process of gas turbine blades begins from destruction of its heat resistant coating. Consequently, the parent metal of the blade is exposed to direct thermal and chemical impact of exhaust gas. First and foremost, it leads to overheating of the blade material manifested by detrimental alterations of its microstructure. The factors which affect that phenomenon include the supercritical temperature, duration of its impact and chemical aggressiveness of the exhaust gas. 
The results obtained from research studies and analyses make it possible to conclude that troubleshooting of gas turbine blades with digital processing of images taken for its surface offers new opportunities to determine the condition of blades after a long-term impact of a working agent at high temperature. One has to note that accuracy of the method which involves digital processing of images acquired for blade surfaces is affected by many factors, such as illumination, contrast, reflection of light, etc.

Information extracted from digital images of blade surfaces and correlated with the outcome of metallographic tests makes it possible to establish the relationship between alterations of the material infrastructure and images of blade surfaces. Such an approach is more reliable than a direct and subjective assessment of blade condition by visual inspection.

\section{References}

[1] Błachnio J., Kułaszka A.: Computer aided visual inspection of the technical condition of gas turbine blades during their operation period. Journal of KONES, Vol. 16, No. 3, 2009, pp. 23-30.

[2] Błachnio J., Bogdan M.: A non-destructive method to assess condition of gas turbine blades, based on the analysis of blade-surface image. Russian Journal of Nondestructive Testing, Vol. 46, No. 11, 2010, pp. 860-866.

[3] Dięgielewski W., Błachnio J., Kułaszka A., Zasada D.: Operation-attributable factors and how they affect condition of heat-resistant coatings of gas-turbine blades. Studies and Proceedings of the Polish Association of Knowledge Management, No. 68, pp. 17-31.

[4] Lewitowicz J., Błachnio J., Barszcz P.,: Techniczna analiza niesprawności i uszkodzeń. Rozdział w monografii: Podstawy eksploatacji statków powietrznych. Wydawnictwo ITWL. Warszawa, 2007. ("Technical analysis of deficiencies and defects". A chapter in the textbook: 'Fundamentals for operation and maintenance of aircrafts'. ITWL Publishing House, Warsaw, 2007).

[5] Majka H., Sieniawski J.: Badania kinetyki i koagulacji fazy $\gamma^{\prime}$ w superstopie niklu EI-867. Archiwum Nauki o Materiałach. T. 4, nr.4, 1998, ss. 237-254. ("Investigation of kinetic phenomena and coagulation of the $\gamma$ ' phase in the EI-876 superalloy" Archives of science on materials, Vol. 4, No. 4, 1998, pp. 237-254).

[6] Mikułowski B.: Stopy żaroodporne i żarowytrzymałe-nadstopy. Wydawnictwo Akademii Górniczo-Hutniczej, Kraków, 1997. ("Heat resistant and high temperature creep resistant alloys - superalloys" - Publishing House of the AGH University of Technology, Cracow).

[7] Патон В.: Жаропрочность литейных никелевых сплавов и защита их от окисления. Наукова Думка, Киев, 1997 ("Heat resistance of nickel-based cast alloys and protection of them against oxidation", Naukova Dumka, Kyiv, 1997.

[8] Pawlak W., Błachnio J.: On the need to maintain homogenous temperature field within the working agent at the intake of a jet engine turbine. Journal of KONES, Vol. 21, No. 1, 2014, pp. 205-213. 
Condition of a gas turbine blade when information on its operating condition...

Próba oceny stanu topatki turbiny gazowej w przypadku ograniczonej informacji...

[9] Raporty z badań. Instytut Techniczny Wojsk Lotniczych. Warszawa, 2010 - 2014. (Investigation reports. Air Force Institute of Technology, Warsaw, 2010 - 2014).

[10] Sieniawski J.: Kryteria i sposoby oceny materiałów na elementy lotniczych silników turbinowych. Politechnika Rzeszowska, 1995. ("Criteria and methods for acceptance of materials for components of avionic turbojet engines", Technical University of Rzeszów, 1995).

[11] Spychała J., Błachnio J., Pawlak W., Kułaszka A.: Assessment of technical condition demonstrated by gas turbine blades by processing of images for their surfaces. Journal of KONBIN, No. 1(21), 2012, pp. 41-50.

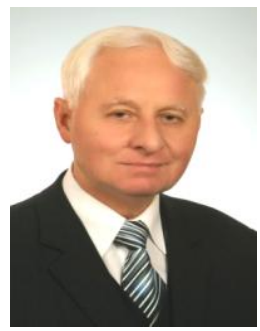

Prof. Józef Btachnio, DSc., Eng. is a researcher at the Air Force Institute of Technology and Technical University of Biatystok. He has been approved by the Ministry of Science of University Education (MNiSzW) as an expert in such fields as aviation, aerospace, material engineering and design and operation of machinery.

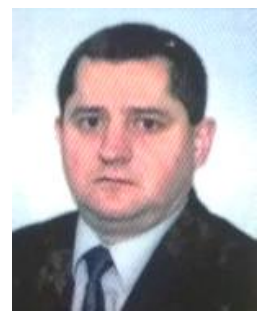

Jarostaw Spychata, PhD., Eng. graduated the Military University of Technology (1987) and majored in aircrafts and helicopters. In 1988, he started his professional career at the Air Force Institute of Technology (ITWL). He has been managing the Division of Aircraft Engines at ITWL since 2004.

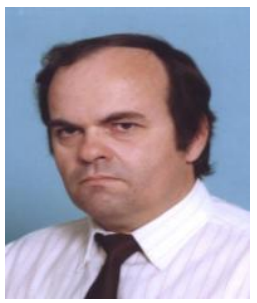

Wojciech Pawlak, PhD., Eng. is a researcher and scientist at the Air Force Institute of Technology. He has majored in modelling of avionic engines operation, in particular systems for automatic control of turbojet engines.

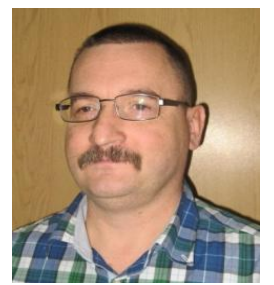

Dariusz Zasada PhD., Eng. graduated from the Mechanical Faculty of the Military University of Technology (WAT) in 1994. He has been employed at WAT since 1995, currently for the Faculty of New Technologies and Chemistry. In 2001, he presented his PhD thesis. 